\title{
Temperature and chalkbrood development in the alfalfa leafcutting bee, Megachile rotundata ${ }^{1}$
}

\author{
Rosalind R. JAMES* \\ USDA-ARS Bee Biology and Systematics Laboratory, Dept. Biology, Utah State University, Logan,
} UT 84322-5310, USA

Received 10 February 2004 - Revised 16 April 2004 - Accepted 29 April 2004

Published online 31 January 2005

\begin{abstract}
Ascosphaera aggregata, the causative agent of chalkbrood in the alfalfa leafcutting bee (Megachile rotundata), is a major mortality factor when this bee is used commercially as a pollinator. The effect of temperature on A. aggregata hyphal growth, spore germination, and disease prevalence was tested. The lowest prevalence of chalkbrood occurred at $35^{\circ} \mathrm{C}$, yet this temperature was the optimum for fungal germination and growth on agar, and is stressful to the insect. Sporulation of M. rotundata cadavers that were infected with the fungus was highest at $25^{\circ} \mathrm{C}$. Daily exposures to $40{ }^{\circ} \mathrm{C}$ for $6 \mathrm{~h}$ did not affect disease incidence, but it negatively impacted spore production. A similar temperature response, that is, where lower temperatures promote the disease, has been seen by others for this bee, and other Ascosphaera spp in other bees, but it is not clear why the greatest likelihood of mycosis does not occur at optimum temperatures for the fungus, or at the temperatures most detrimental to the insect. A few hypotheses have been proposed, but empirical data are lacking.
\end{abstract}

alfalfa leafcutting bee / Megachile rotundata / Ascosphaera aggregata / chalkbrood / temperature stress

\section{INTRODUCTION}

Ascosphaera aggregata causes chalkbrood disease in larvae of the solitary alfalfa leafcutting bee, Megachile rotundata (Fabricius) (Hymenoptera, Megachilidae). The alfalfa leafcutting bee is used extensively in the Northwestern US and Canada for pollination of alfalfa seed. Kish et al. (1979) and Stephen et al. (1981) report that larval mortality from chalkbrood can exceed $65 \%$ in the Northwestern US, and the disease is still prevalent in this area today (James, unpublished data). In Canada, the disease is much less prevalent, and in some regions, such as Saskatchewan, A. aggregata does not occur at all (Goerzen et al., 1992). The prevalence of chalkbrood in Canada is enough lower than in Northwestern US, that many Northwestern US seed growers regularly purchase bees from Canada in order to obtain a clean supply for their pollination needs.

Vandenberg (1992) found $M$. rotundata from Canada and the US to have equal susceptibility to chalkbrood, so differential susceptibility is not the cause for differences in disease incidence. Other possible causes are many-fold, and could include human, as well as, environmental factors. One possible environmental factor is climate. Much of the alfalfa growing region of Canada has a colder climate than that of the Northwestern US [except for Montana and Wyoming, which also have low levels of chalkbrood (Kim Decker, unpublished data from a 20-year screening)].

* Corresponding author: rjames@biology.usu.edu

${ }^{1}$ Manuscript editor: Marla Spivak 
Outdoor winter weather conditions are probably inconsequential to chalkbrood occurrence because $A$. aggregata infects larvae during the field growing season, and larval death and fungal spore production are complete before the end of the summer. Furthermore, managed bees are usually stored overwinter at $4{ }^{\circ} \mathrm{C}$ (as prepupae), under controlled conditions. More relevant might be the conditions that occur during the nesting season, when infection and disease development occur. Summer temperatures might reduce the prevalence of the disease in colder climates by lowering the proportion of bees that produce multiple generations in a season, and thus reduce spread of the pathogen because fewer bees will be re-nesting in the same holes within a season [as suggested by Goettel et al. (1995)].

Summer temperatures might also reduce the susceptibility of larvae to disease. Unlike most entomopathogenic fungi, A. aggregata infects its host through the gut (Vandenberg and Stephen, 1983; McManus and Youssef, 1984). Larvae become exposed to chalkbrood when the pollen provision is contaminated with spores, most likely by the mother bee. Vandenberg and Goettel (1995) tested the effects of temperature on larval infection rates by rearing larvae on diet that was artificially contaminated with spores. They then determined the dose response at different temperatures, and the lowest infection rates occurred at $37{ }^{\circ} \mathrm{C}$ (the warmest temperature treatments).

I tested a wider range of temperatures than Vandenberg and Goettel (1995) to determine both the upper and lower temperature threshold for A. aggregata growth and germination. In addition to testing the effects of temperature in vitro for the fungus, I also test for effects on disease incidence and sporulation in the host using field collected larvae naturally exposed to the pathogen. Previous experimenters have added spores to the pollen provision in an aqueous suspension to increase infection levels (e.g. Vandenberg and Stephens, 1982; McManus and Youssef, 1984; Rust and Torchio, 1992; Torchio, 1992; Vandenberg, 1992, 1994; Goettel et al., 1995); however, I wanted to avoid having to modify the pollen provision because wetting the provision can sometimes affect larval health in solitary bees (Torchio, 1992; Vandenberg, 1994).

\section{MATERIALS AND METHODS}

\subsection{Temperature and A. aggregata growth rate}

Circular pieces of cultures of A. aggregata hyphae (plugs) were placed on fresh agar and grown at different temperatures to determine the effect of temperature on hyphal growth. To make the plugs, a uniform lawn of $A$. aggregata (originally isolated from a sporulating $M$. rotundata cadaver) on plates of a modified version of the V-8 juice plug agar developed by Youssef and McManus (1991). The agar medium was composed of $50 \mathrm{~mL}$ low sodium V-8 Juice (Campbell Soup Co., Camden, NJ), $5.3 \mathrm{~g}$ maltose, $1.6 \mathrm{~g}$ yeast extract, $0.11 \mathrm{~g} \mathrm{MgSO}_{4}, 0.04 \mathrm{~g}$ thiamine, $1.1 \mathrm{mg}$ biotin, $7.5 \mathrm{~mL}$ Graces Medium (Invitrogen Co., Grand Island, NY), $0.5 \mathrm{~mL}$ canola oil, $0.5 \mathrm{~mL}$ of $0.1 \%$ Triton $\mathrm{X}-100$, and $1.5 \mathrm{~g}$ agar, and enough deionized water to bring the volume to $100 \mathrm{~mL}$. The $\mathrm{pH}$ was adjusted to 6.0 before autoclaving. I refer to this agar as modified V-8 agar.

The fungal lawns were grown for a week at $32{ }^{\circ} \mathrm{C}$, and plugs of hyphae were cut from the plates using a sterilized \#2 (6 mm inside diameter) cork borer. Each hyphal plug was placed in the center of a fresh plate (100 mm diameter) of modified V-8 agar and incubated at one of the following temperatures: 10 , $15,20,25,30,35,40$, or $45^{\circ} \mathrm{C}\left( \pm 1^{\circ} \mathrm{C}\right.$, each $)$, for $10 \mathrm{~d}$. Two lines were drawn on the back of each plate across the center of the plug and crossing one another at $90^{\circ}$. The diameter of each fungal colony was measured along the two lines and averaged after $3 \mathrm{~d}$ incubation. The diameter of fungal colony was again measured in this way after $10 \mathrm{~d}$ incubation. The growth rate was determined by taking the average daily increase in diameter that occurred between these two dates. A similar method for determining fungal growth rates has previously been used by several others [e.g. (Hall and Bell, 1961; Welling et al., 1994; Fargues et al., 1997; Ouedraogo et al., 1997; Vidal et al., 1997; James et al., 1998; Ekesi et al., 1999; Davidson et al., 2003)]. For each temperature, nine separate plates were set up on three different dates (Feb. 3, 10, and 24, 2003). Each plate was considered a replicate. To test whether temperature had a significant effect on the growth rate, regression analysis was used after a log transformation of both the dependent variable (mean growth per day) and the independent variable (temperature) using Proc Reg (SAS, 1999). At some temperatures, no growth occurred, and these data were excluded from the regression analysis.

\subsection{Temperature and A. aggregata spore germination}

A. aggregata spores were incubated at different temperatures to determine the upper and lower limits 
for spore germination. To do this, $M$. rotundata cadavers with fully sporulating A. aggregata were collected from the field in May of the previous year and stored at $4{ }^{\circ} \mathrm{C}$. For each experimental run (replicate block), spores were scraped off of five cadavers and mixed together in a $1 \mathrm{~mL}$ sterile plastic microcentrifuge tube, and then ground gently using a plastic pestle to break apart the spore balls. The spores were mixed with $1 \mathrm{~mL}$ of sterile deionized water, using a vortex mixer on the highest setting for $2 \mathrm{~min}$, to further break apart the spores. The large particles in the suspension were allowed to settle for $20 \mathrm{~min}$, and then a sample of approximately $0.1 \mathrm{~mL}$ was taken from the middle of the suspension using a pipette. This sample was diluted approximately 10fold to obtain a concentration of $6.0 \times 10^{7}$ spores per $\mathrm{mL}$. A haemocytometer was used to determine the concentration and dilution factor.

The spores were then incubated in modified V-8 broth [the same medium described above, except without the agar, and the V-8 Juice was filtered through miracloth (C. N. Biosciences, La Joya, CA) to facilitate microscopic examination of the spores after incubation]. We mixed $0.8 \mathrm{~mL}$ of broth and $0.1 \mathrm{~mL}$ of spore suspension in each of 42 microcentrifuge tubes (1.5-mL capacity), to obtain a final concentration of $7.5 \times 10^{6}$ spores $/ \mathrm{mL}$. The tubes of spore-broth mix were placed in groups of six in seven different microcentrifuge racks. The tube lids were left open, and the tubes were placed inside zip locking plastic bags that were then filled with $\mathrm{CO}_{2}$ and sealed. Each rack was incubated at one of the following temperatures: $10,15,20,25,30,35$, and $40{ }^{\circ} \mathrm{C}\left( \pm 1^{\circ} \mathrm{C}\right.$, each $)$. After $6,12,18,24,36$ and $48 \mathrm{~h}$ of incubation, one of the tubes was removed from each incubator to determine spore germination. The bags were refilled with $\mathrm{CO}_{2}$ at these times. The entire experiment was repeated on three different dates (Jan. 27, Feb. 4, and Mar. 5, 2003), and each of these experimental runs was a replicate block.

Spore germination was determined by briefly mixing the spore-broth mixture on a vortex mixer, and then quickly taking a $10 \mu \mathrm{L}$ sample and placing it on a glass slide. Two such samples were taken from each tube, and each sample on a slide was covered with a glass coverslip. Using phase contrast microscopy at 400-600x magnification, the slide was visually scanned in a systematic fashion, and all the spores in each field of view were evaluated for germination until the number of spores that had been examined reached 100 . This process was repeated for each droplet, yielding a total of 200 spores for each temperature, time, and replicate.

Data were statistically analyzed using an arcsinesquare root transformation of percent germination. For each experiment, the minimum significant difference (Tukey's HSD, Proc GLM)(SAS, 1999) for the $95 \%$ probability level was calculated and used to determine whether any two temperatures were significantly different from each other, for each time period.

\subsection{Effect of temperature on prevalence of infection in bee larvae}

To test the effect of temperature on the prevalence of disease in $M$. rotundata larvae, nest cells with eggs and provision were collected from a commercial alfalfa seed field located near Tremonton, UT, on ten different days between Aug. 1-21, 2003. For each egg collection, nests were collected from the field, and brought into the lab, where the top of each cell was opened to verify that it contained an egg. The sample of collected eggs (in their cells) was randomly mixed and then divided evenly between five temperature treatments: a constant temperature of $15,20,25$, or $35^{\circ} \mathrm{C}\left( \pm 1{ }^{\circ} \mathrm{C}\right.$. each $)$, and a fluctuating temperature of $20^{\circ} \mathrm{C}$ for $18 \mathrm{~h}$ and $40^{\circ} \mathrm{C}$ for $6 \mathrm{~h}$ (it took the incubator about $1.5 \mathrm{~h}$ to come to the new temperature after each temperature change). The number of eggs collected each day varied from 80 to 1150 , but on each date of collection, we divided the eggs randomly, but evenly, between all the temperature treatments, yielding an average of 57 eggs per day, for each temperature. Each date of egg collection was considered a replicate block.

Nest cells containing eggs were placed in 96-well tissue culture plates and incubated under the different temperature treatments until all the larvae either died or survived to spin a cocoon (the overwintering stage for this insect is a prepupa in a cocoon). A. aggregata spores were not added to the provisions. The field endemic level of chalkbrood was assumed to be sufficient in field collected samples to provide the moderate levels of infection that were needed.

Any eggs that did not hatch were not included in the assays because we assumed that this mortality was due to handling and not chalkbrood. Thus, even though the eggs were divided up evenly between treatments for each collection date, the resulting sample size varied somewhat between treatments depending on how many eggs died from handling. Approximately $11 \%$ of the eggs died before hatching, except at $15{ }^{\circ} \mathrm{C}$, where $35 \%$ of the eggs never hatched.

Saturated solutions of glucose in closed containers were used to maintain relative humidity at $50 \% \mathrm{RH}$ in all the treatments. We selected $50 \% \mathrm{RH}$ because if the air is too dry, the larval provisions might dry out, and if it is too wet, then mold will grow on the provision. However, our containers did not seal well, and the average humidity was $66 \%$, fluctuating between 62 and $72 \%$, except for $25^{\circ} \mathrm{C}$, where the average RH was $85 \%$, fluctuating between 75 and $90 \%$. We do not expect humidity to play as important a role in the initiation of infection as it does for most 
entomopathogenic fungi because the A. aggregata germinates in the larval gut, where it is protected from ambient humidity. However, humidity might affect the ability of the fungus to sporulate.

At the end of the experiment, the number of larvae that died from chalkbrood was assessed. A. aggregata spores and ascomata (spore cysts) were produced over the entire surface of the larva in most cases of chalkbrood. When this occurred, the larva were dark gray to black and shiny. The shine is a result of the spores and ascomata being produced under the cuticle of the insect, a characteristic of $A$. aggregata. When the cuticle is broken, the spores take on a powdery appearance. In some cases, only part of the cadaver was covered in spores, or no spores were produced. Larvae that had died from chalkbrood infections that did not sporulate were white and had a hard, dry texture and maintained the shape of a live larva; where as, larvae that died from other causes might be white, but were soft or they shriveled and collapsed when drying out, or they might be black or brown with a texture similar to that of cheddar cheese. We collected the bees as eggs, so no predators or parasites were found in these experiments.

To determine if temperature affected the ability of the fungus to produce spores in a cadaver, I separated sporulating cadavers from non-sporulating cadavers. Some cadavers produced spores, but distinctly fewer spores than normal. Cadavers with very few ascomata often are empty of spores, or the few spores present have poor viability (James, unpublished data). For this reason, if less than $10 \%$ of a cadaver was covered in spores, it was considered to be non-sporulating, as estimated by eye.

The size of each dead larva was also recorded, dividing cadavers into four size categories: small, medium, large, and prepupae. Large larvae were those that were fully formed at the time of death, unless they had spun a cocoon, then they were considered prepupae. Small larvae were the size of a first or second instar, and the remaining larvae were medium. Size classes were used because it is difficult to determine the instar of diseased larvae.

Logistic ANOVA (Proc Logistic, SAS, 1999) was used to compare among temperature treatments, the proportion of larvae that lived, that were infected with chalkbrood, or that died from other causes. Logistic ANOVA was also used to test the effect of temperature on the proportion of cadavers with $A$. aggregata mycosis that had sporulated. Very few larvae survived at $15^{\circ} \mathrm{C}$, and so this temperature was not used in the chalkbrood comparisons. Thus, we had four temperature regimes and six pair-wise comparisons. For this reason, the $\alpha$-level was adjusted to 0.0085 to give a $P$-value of $0.05 \%$ (using a Bonferroni adjustment in the $P$-value). Thus the $95 \%$ confidence intervals for the log-means were also

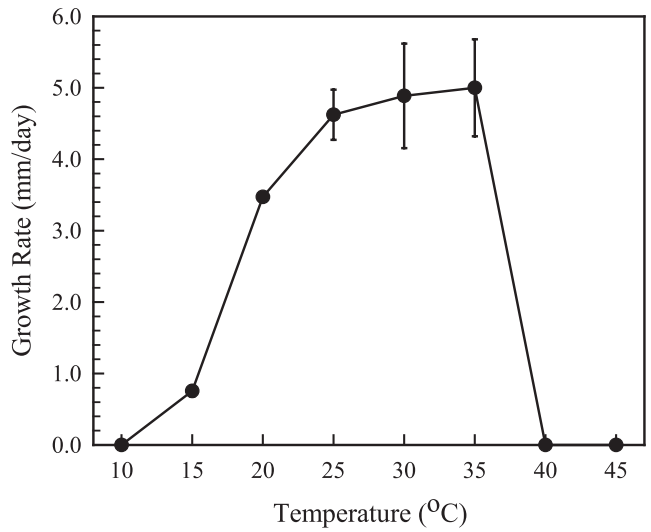

Figure 1. Hyphal growth rate in nutrient agar for Ascosphaera aggregata incubated at different temperatures. Points are means from nine plates (averaged over $7 \mathrm{~d}$ ). The bars represent the standard error of the mean.

adjusted to $99.15 \%$ using an $\alpha$ of 0.0085 . In this way, we could do a pair-wise comparison of all the means using the confidence intervals. For the proportion of live larvae, we included the $15{ }^{\circ} \mathrm{C}$ data, and so $\alpha$ was adjusted to 0.005 for the $95 \%$ confidence intervals. We treated temperature as a class variable in these analyses (i.e. used ANOVA instead of regression analysis) because one of the temperatures was variable, and thus did not fit in a regression.

A contingency table and chi-square test was used to determine if the proportion of chalkbrood cadavers in each larval size class was independent of temperature. A total of 1047 insects died from chalkbrood in the experiment, comprising the total sample size for the contingency table. The total number of insects tested was 2848 .

\section{RESULTS}

\subsection{Temperature and A. aggregata growth rate}

As one might expect, temperature had a significant effect $\left(\mathrm{F}=58.34, P \leq 0.0001, r^{2}=\right.$ 0.58 ) on hyphal growth rate (Fig. 1). The regression equation for temperatures between 15 and $35^{\circ} \mathrm{C}$ was:

$$
\begin{gathered}
\log _{10}(\text { growth })=1.31(\mathrm{SE}=0.24) \\
\times \log _{10}(\text { temperature })-1.18(\mathrm{SE}=0.17) .
\end{gathered}
$$

Temperature is in ${ }^{\circ} \mathrm{C}$, and growth is $\mathrm{mm} / \mathrm{d}$. The upper and lower temperature limits for hyphal growth were $35^{\circ} \mathrm{C}$ and $15^{\circ} \mathrm{C}$. No 
Table I. Mean percent spore germination readings (and 95\% confidence intervals) for Ascosphaera aggregata incubated in nutrient broth at different temperatures. Means and confidence intervals are transformed back from an arcsine-square root transformation. Means in a column followed by the same letter are not significantly different $(P \leq 0.05$, Tukey's HSD).

\begin{tabular}{lcccccc}
\hline \multirow{2}{*}{$\begin{array}{l}\text { Temperature } \\
\left({ }^{\circ} \mathrm{C}\right)\end{array}$} & \multicolumn{5}{c}{ Hours of Incubation } \\
\cline { 2 - 7 } & 6 & 12 & 18 & 24 & 36 & 48 \\
\hline 10 & $0 \mathrm{a}$ & $1.1(0.1-5.4) \mathrm{a}$ & $0.7(0.0-3.6) \mathrm{a}$ & $6.1(2.2-11.7) \mathrm{ad}$ & $21.4(13.3-30.8) \mathrm{ac}$ & $16.7(12.1-21.9) \mathrm{a}$ \\
15 & $2.2(1.3-3.2) \mathrm{b}$ & $11.7(4.7-21.2) \mathrm{ab}$ & $13.6(7.3-21.4) \mathrm{abc}$ & $13.0(7.0-20.4) \mathrm{ad}$ & $30.9(21.4-41.2) \mathrm{a}$ & $24.3(18.9-30.1) \mathrm{a}$ \\
20 & $7.5(5.9-9.2) \mathrm{bc}$ & $26.1(15.6-38.2) \mathrm{ab}$ & $23.9(15.6-33.2) \mathrm{bcd}$ & $26.1(17.8-35.3) \mathrm{ab}$ & $49.7(39.0-60.4) \mathrm{ab}$ & $48.5(42.0-55.1) \mathrm{b}$ \\
25 & $10.1(8.3-12.0) \mathrm{c}$ & $44.5(31.9-57.4) \mathrm{b}$ & $40.2(30.2-50.5) \mathrm{cd}$ & $50.0(40.1-59.9) \mathrm{bc}$ & $55.1(44.3-65.6) \mathrm{ab}$ & $60.0(53.5-66.4) \mathrm{bc}$ \\
30 & $28.5(25.7-31.3) \mathrm{de}$ & $43.6(31.1-56.6) \mathrm{b}$ & $53.2(42.8-63.4) \mathrm{d}$ & $51.8(41.8-61.6) \mathrm{bc}$ & $73.2(63.2-82.2) \mathrm{b}$ & $72.7(66.7-78.4) \mathrm{c}$ \\
35 & $39.5(36.5-42.5) \mathrm{d}$ & $47.8(35.0-60.7) \mathrm{b}$ & $53.3(43.0-63.6) \mathrm{d}$ & $66.0(56.3-75.1) \mathrm{c}$ & $81.2(72.1-88.9) \mathrm{b}$ & $77.5(71.8-82.7) \mathrm{c}$ \\
40 & $24.2(21.6-26.9) \mathrm{e}$ & $33.9(22.3-46.6) \mathrm{b}$ & $6.5(2.4-12.6) \mathrm{ab}$ & $2.9(0.5-7.1) \mathrm{d}$ & $2.4(0.2-6.8) \mathrm{c}$ & $0.8(0.1-2.4) \mathrm{d}$ \\
\hline
\end{tabular}

growth occurred at $10^{\circ} \mathrm{C}$, nor at $40^{\circ} \mathrm{C}$ and above (and so these temperatures were not included in the regression).

\subsection{Temperature and A. aggregata spore germination}

The temperature range for spore germination was broader than for hyphal growth. Germination occurred over the entire temperature range tested $\left(10-40^{\circ} \mathrm{C}\right)(\mathrm{Tab}$. I). Germination was already well underway after only six hours of incubation at $30{ }^{\circ} \mathrm{C}$ and above, but at $10{ }^{\circ} \mathrm{C}$, germination never exceeded $22 \%$. Germination reached an asymptote at 36 hours, for all temperatures except $25^{\circ} \mathrm{C}$. However, even at this temperature, germination increased very little after $24 \mathrm{~h}$. At $40^{\circ} \mathrm{C}$, the spores started germinating after 6-12 $\mathrm{h}$ incubation, but after that, they began to lyse. It is this lysing of the germinating spores that accounts for the decline in cumulative germination over time at this temperature.

\subsection{Effect of temperature on prevalence of infection in bee larvae}

Larval survival was not adversely affected by temperature, except at $15^{\circ} \mathrm{C}$ (based on adjusted 95\% CI, Fig. 2). Fifteen degrees appeared to be below the developmental threshold for this bee because many eggs did not hatch, few larvae survived the duration of the experiment, and none of these completed development. For this reason, this temperature was not included in the statistical analysis (only
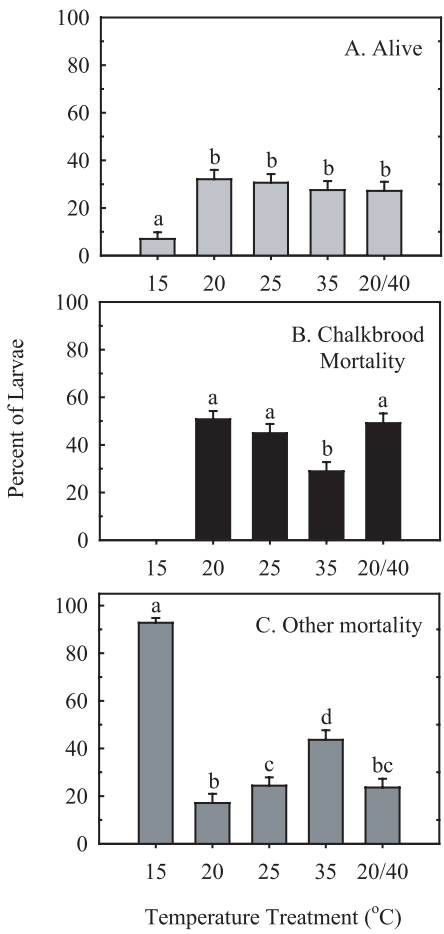

Figure 2. Mean percent of Megachile rotundata larvae that were alive (A), that died from chalkbrood infections (B), or that died from other causes (C), when reared under different temperature regimes. Means are a percent of all the larvae tested, in all cases. Temperatures are all constant except for one variable treatment (20/40), using $20^{\circ} \mathrm{C}$ for $18 \mathrm{~h}$, and $40{ }^{\circ} \mathrm{C}$ for $6 \mathrm{~h}$ each day. Lines at the top of the bars are the Bonferroni-adjusted confidence intervals (see text for $\alpha$ levels used). Means with confidence intervals that do not overlap are significantly different $(P \leq 0.05)$, as indicated by having different letters above the bars. 
one larva showed chalkbrood symptoms). Temperature had a significant effect on disease occurrence for chalkbrood $\left(\chi^{2}=66.35\right.$, d.f. $=3, P<0.0001$ ), with the least amount of disease occurring at $35^{\circ} \mathrm{C}$ (Fig. 2).

Mortality other than chalkbrood also occurred in the experiments. None of this mortality was due to predation or parasitism because we used eggs collected from the field, and then incubated them away from predators and parasites. Some of the other mortality was due to other diseases, but most was due to an unknown cause which we attribute to temperature stress. The greatest non-chalkbrood mortality occurred at $15^{\circ} \mathrm{C}$ and $35^{\circ} \mathrm{C}$ (Fig. 2), and nearly all of this was due to the unknown cause. Short periods of $40{ }^{\circ} \mathrm{C}$ did not increase larval mortality.

Sporulation of cadavers was also influenced by temperature $\left(\chi^{2}=78.37\right.$, d.f. $=3, P<$ $0.0001)$, with the lowest incidence of sporulation occurring in the variable temperature regime $\left(20 / 40^{\circ} \mathrm{C}\right)$ and the highest incidence occurring at $25^{\circ} \mathrm{C}$ (Fig. 3). The $25^{\circ} \mathrm{C}$ temperature treatment also had the highest level of $\mathrm{RH}$, which may have affected spore production.

Temperature had a significant affect on the size of larvae at the time of death for insects infected with chalkbrood $\left(\chi^{2}=38.33\right.$, d.f. $=9$, $P \leq 0.001)$. At most temperatures, approximately $80 \%$ of the larvae that died from chalkbrood attained a large size before death, but at $35^{\circ} \mathrm{C}$, only $76.2 \%$ of the chalkbrood cadavers were large, and proportionally more cadavers were medium or small (Tab. II). Conversely, in the $20 / 40{ }^{\circ} \mathrm{C}$ treatment, $88 \%$ of the chalkbrood cadavers were large, and fewer medium and small cadavers occurred.

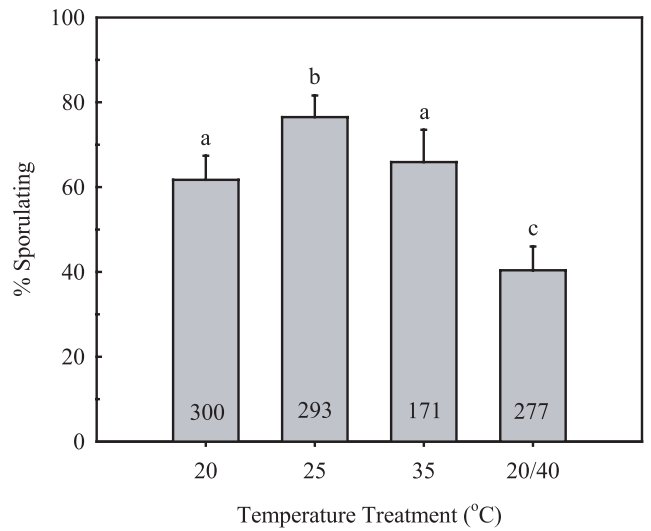

Figure 3. Mean percent sporulation of A. aggregate in larvae infected with chalkbrood and incubated at different temperatures. Lines at the top of the bars are the Bonferroni-adjusted confidence intervals $(\alpha=0.0085)$. Bars with the same letters above them are not significantly different $(P \leq 0.05)$. Numbers at the bottom of the bar represent the total number of larvae included in that treatment.

\section{DISCUSSION}

The optimum temperature for the fungus was $35^{\circ} \mathrm{C}$ for both growth and germination, with $25-35^{\circ} \mathrm{C}$ being the peak activity range. Hyphal growth was more sensitive to temperature than was spore germination, with no growth occurring at $40{ }^{\circ} \mathrm{C}$ and above, or at $10^{\circ} \mathrm{C}$ or below. A. apis, the causative agent of chalkbrood in honey bees, has a temperature threshold range similar to that reported here for A. aggregata, but the range is more restricted and slightly higher (germination only occurred at $25-40^{\circ} \mathrm{C}$ ) (Bamford and Heath, 1989).

Table II. The percent of chalkbrood cadavers that fell into each size class for each temperature treatment. The proportion of cadavers in each size class was significantly affected by temperature $\left(\chi^{2}=38.33\right.$, d.f. $=9, P \leq 0.001)$.

\begin{tabular}{lcccc}
\hline $\begin{array}{l}\text { Temperature } \\
\left({ }^{\circ} \mathrm{C}\right)\end{array}$ & $\begin{array}{c}\text { Small } \\
\text { larvae }\end{array}$ & $\begin{array}{c}\text { Medium } \\
\text { larvae }\end{array}$ & $\begin{array}{c}\text { Large } \\
\text { larvae }\end{array}$ & Pre-pupae \\
\hline 20 & 0.30 & 11.7 & 82.7 & 5.0 \\
25 & 2.7 & 9.7 & 79.5 & 8.1 \\
35 & 6.1 & 15.2 & 76.2 & 2.4 \\
$20 / 40$ & 1.4 & 4.9 & 88.1 & 5.6 \\
\hline
\end{tabular}


The effects of temperature on A. aggregata growth and spore germination in vitro contrasted sharply with what was observed in the host. Disease occurs when the pathogen successfully invades the host, and the incidence of disease was greatest at the lowest temperature $\left(20^{\circ} \mathrm{C}\right)$, and lowest at the highest constant temperature $\left(35^{\circ} \mathrm{C}\right.$; Fig. 2$)$, an indication that high temperatures may inhibit disease development, even when they are at the optimum temperature for in vitro growth of the fungus. However, short daily periods of $40{ }^{\circ} \mathrm{C}$ were not detrimental to disease development (Fig. 2). Humidity levels were not adequately controlled in this experiment, but they did not correlate with chalkbrood incidence and so probably had little, if any, effect on infection rates.

Peak sporulation occurred at $25^{\circ} \mathrm{C}$, the intermediate temperature. This is also the temperature with the highest $\mathrm{RH}$ levels, and so the increase in the number of cadavers that sporulated may have been due to higher humidity. However, the number of cadavers that sporulated at the variable temperature regime (20/ $40^{\circ} \mathrm{C}$ ) was significantly less than for a constant $20^{\circ} \mathrm{C}$, even though the relative humidity conditions were similar, an indication that higher temperatures, even for short periods, might inhibit spore production.

Vandenberg \& Goettel (1995) found that the lowest $\mathrm{LC}_{50}$ occurred at the lowest temperatures tested $\left(25\right.$ and $\left.30{ }^{\circ} \mathrm{C}: 10{ }^{\circ} \mathrm{C}(18: 6 \mathrm{~h})\right)$, although they report no effect of temperature on cadaver size. We found that most larvae that died from chalkbrood died as fully sized larvae, but before they formed a cocoon. At $35^{\circ} \mathrm{C}$, a greater percentage of larvae died before they attained a full size, but still, the majority of cadavers were similar in size to fully developed larvae. This report is the first record of the typical size, or age, at which larvae die from chalkbrood. The increase in smaller cadavers seen at $35{ }^{\circ} \mathrm{C}$ may be due to an increased growth rate of the fungus at this temperature, or a decreased growth rate of the larvae (Whitfield et al., 1987).

A. apis is similar to A. aggregata in that greater infection rates occur at lower temperatures $\left(25-30{ }^{\circ} \mathrm{C}\right.$ ), or if the larvae are chilled (Bailey, 1967; Flores et al., 1996). Likewise, Rust and Torchio (1992) found a greater prevalence of chalkbrood at lower temperatures for $A$. torchioi infections in the blue orchard bee (Osmia lignaria propinqua Cresson). Unfortunately, humidity was neither controlled nor reported in any of these reports.

Bailey (1967) suggests that chilling the larvae allows more oxygen to flow to the tissues, and in this way facilitates growth of the pathogen. However, he does not offer any supporting evidence that this actually occurs. Rust and Torchio (1992) suggest that lower temperatures promote infection because insect development is delayed, and the period of time that the larval gut remains blind is extended, increasing chances for infection. However, I found that fungal development is also retarded at the cooler temperatures. Furthermore, the lowest levels of mycosis reported here are at $35^{\circ} \mathrm{C}$, a temperature where development is delayed slightly (Whitfield et al., 1987). In reality, the development rate of $M$. rotundata larvae is nearly asymptotic with respect to temperature, and so the development rates at 25 and $35^{\circ} \mathrm{C}$ are not much different (Whitfield et al., 1987), but importantly, development is not faster and so the blind gut period is not shorter at 35 versus $25^{\circ} \mathrm{C}$.

I previously reported a similar temperature response for another entomopathogenic fungus (Beauveria bassiana) in larvae of a beetle host (Hippodamia convergens) (James et al., 1998), where the optimum temperature for germination and growth of the pathogen occurred at much warmer temperatures than the optimum for mycosis. In both cases, the beetle and the alfalfa leafcutting bee, temperature affected the interaction between the host and pathogen, and thus the ability of a pathogen to cause disease cannot be fully understood by knowing the effect of temperature on the in vitro growth response of the pathogen. A better understanding of the insects' physiological responses to both fungal pathogen invasion and temperature stress is needed in order to better understand how temperature affects the ability the insect host to resist infection.

\section{ACKNOWLEDGEMENTS}

Craig Huntzinger, Amber Williams, and Suzy Dooley provided technical assistance in conducting the bioassays and the field collections of eggs. Paul and Roger Munn and JWM Leafcutters, Inc. allowed us access to their fields and bees for collecting bee eggs. Without all of their help, such a large scale egg 
collection would not have been possible. William Kemp, William Meikle, John Vandenberg, and two anonymous reviewers provided comments that contributed considerably to improving this paper.

Résumé - Température et développement du couvain plâtré chez l'abeille Megachile rotundata. Ascosphaera aggregata est un champignon qui provoque le couvain plâtré chez l'abeille découpeuse de la luzerne, Megachile rotundata (Fabricius). M. rotundata est une abeille solitaire élevée sur une grande échelle pour la pollinisation de la luzerne en production de semences et cette maladie constitue un facteur important de mortalité. La croissance d'A. aggregata et le taux de germination des spores ont été déterminés in vitro à l'intérieur d'une large gamme de températures constantes $\left(10-45^{\circ} \mathrm{C}\right)$. La prévalence de cette maladie (proportion des individus atteints/nombre total d'individus) chez les larves a été aussi déterminée pour les divers régimes de température. Les œufs ont été récoltés en plein champ et mis à incuber à différentes températures : température constante de $15,20,25$ ou $35^{\circ} \mathrm{C}$ et traitement à température variable $\left(18 \mathrm{~h}\right.$ à $20^{\circ} \mathrm{C}$ et $6 \mathrm{~h}$ à $40^{\circ} \mathrm{C}$ ). Des provisions naturelles de pollen ayant des niveaux naturels de contamination par A. aggregata ont été fournies. L'incidence la plus faible du couvain plâtré a eu lieu à $35^{\circ} \mathrm{C}$ (Fig. 2), alors que cette température est optimale pour la germination des spores (Tab. I) et la croissance des hyphes (Fig. 1). Cette température est aussi stressante pour l'insecte, ce qui augmente la mortalité qui n'est pas due au couvain plâtré. La probabilité pour le champignon de produire des spores dans une larve morte a été la plus faible dans le traitement à température variable et la plus forte à $25^{\circ} \mathrm{C}$ (Fig. 2). Pourtant, à cette température l'humidité relative était aussi la plus élevée. Bien que de courtes expositions journalières à $40^{\circ} \mathrm{C}$ n'aient pas affecté l'incidence de la maladie (Fig. 3), elles ont réduit significativement la production de spores (Fig. 3).

Une réduction similaire du taux de maladie parallèlement à une augmentation de la température a déjà été notée par d'autres auteurs pour cette abeille (Vandenberg et Goettel, 1995), pour Osmia lignaria propinqua avec A. torchioi (Rust et Torchio, 1992) et pour Apis mellifera avec A. apis (Bailey, 1967 ; Flores et al., 1996). La raison pour laquelle la plus grande probabilité de survenue de cette mycose n'a pas lieu aux températures optimales pour la croissance et la germination d'Ascopharea spp. n'est pas claire, mais cela doit être dû à quelque interaction entre le champignon et l'hôte. Quelques idées sont proposées, mais les données empiriques manquent.

Megachile rotundata / Ascospharea aggregata / couvain plâtré / stress thermique

Zusammenfassung - Temperatur und Kalkbrutentwicklung in der Luzernen Blattschneiderbiene. Ascosphaera aggregata ist ein Pilz, der bei der Blattschneiderbiene der Luzerne (Megachile rotundata) Kalkbrut verursacht. M. rotundata ist eine Solitärbiene, die in großem Umfang für die Bestäubung der Luzernenfelder eingesetzt wird. Der Pilzbefall hat eine große ökonomische Bedeutung für die Haltung.

Das Wachstum von A. aggregata und die Sporenreifung wurden in vitro für einen großen, jeweils konstanten Temperaturbereich $\left(10-45^{\circ} \mathrm{C}\right)$ bestimmt. Die Anfälligkeit der Larven für die Krankheit wurde ebenfalls für verschiedene Temperaturen bestimmt. Die Eier wurden im Freiland gesammelt und dann bei unterschiedlichen Temperaturen im Brutschrank gehalten (konstant $15^{\circ} \mathrm{C}, 20^{\circ} \mathrm{C}, 25^{\circ} \mathrm{C}$ oder $35^{\circ} \mathrm{C}$, und eine variable Temperaturbehandlung von $20 /$ $40{ }^{\circ} \mathrm{C}$ für $18 / 6 \mathrm{~h}$ ). Dabei wurde natürlicher Pollenvorrat mit natürlichen Kontaminationsmengen eingesetzt. Der niedrigste Ausbruch von Kalkbrut lag bei $35^{\circ} \mathrm{C}$ (Abb. 2), diese Temperatur ist jedoch das Optimum für die Sporenbildung (Tab. I) und das Hyphenwachstum (Abb. 1). Eine Temperatur von $35^{\circ} \mathrm{C}$ ist auch für die Biene ungünstig und steigert auch die von Kalkbrut unabhängige Mortalität. Die niedrigste Wahrscheinlichkeit für eine Sporenerzeugung des Pilzes zeigte sich bei toten Larven, die bei unterschiedlichen Temperaturen gehalten wurden. Bei $25^{\circ} \mathrm{C}$ war die Sporenerzeugung am höchsten. (Abb. 2); bei dieser Temperatur war jedoch die relative Luftfeuchtigkeit ebenfalls am höchsten. Kurze tägliche Erwärmungen auf $40{ }^{\circ} \mathrm{C}$ hatten keinen Einfluss auf das Auftreten der Krankheit. (Abb. 3). Allerdings führten diese Erwärmungen $\mathrm{zu}$ einer signifikant reduzierten Sporenproduktion (Abb. 3). Eine ähnliche Verringerung der Infektionsrate durch Erhöhung der Temperatur wurde auch von anderen Autoren beobachtet (Vandenberg und Goettel, 1995). Ähnliches gilt bei Befall von Osmia lignaria propinqua mit $A$. torchioi (Rust und Torchio, 1992) und bei Befall der Honigbiene mit A. apis (Bailey, 1967; Flores et al., 1996). Es ist unklar, warum der höchste Pilzbefall nicht bei den Temperaturen auftritt, die das Optimum für Wachstum und Sporenbildung von Ascosphaera spp. sind. Allerdings muss das mit interaktiven Wirkungen zwischen Pilz und Wirt zusammenhängen. Es werden dazu einige Ideen vorgestellt, aber empirische Daten fehlen.

Luzernen Blattschneiderbiene / Ascosphaera aggregata / Kalkbrut / Megachile rotundata / Temperaturstress

\section{REFERENCES}

Bailey L. (1967) The effect of temperature on the pathogenicity of the fungus, Ascosphaera apis, for larvae of the honey bee, Apis mellifera, in: van der Laan P.A. (Ed.), Insect Pathology and Microbial Control, North-Holland Pub. Co., Netherlands, pp. 162-167. 
Bamford S., Heath L.A.F. (1989) The effects of temperature and $\mathrm{pH}$ on the germination of spores of the chalkbrood fungus, Ascosphaera apis, J. Apic. Res. 28, 36-40.

Davidson G., Phelps K., Sunderland K.D., Pell J.K., Ball B.V., Shaw K., Chandler D. (2003) Study of temperature-growth interactions of entomopathogenic fungi with potential for control of Varroa destructor (Acari: Mesostigmata) using a nonlinear model of poikilotherm development, J. Appl. Microbiol. 94, 816-825.

Ekesi S., Maniania N.K., Ampong-Nyarko K. (1999) Effect of temperature on germination, radial growth and virulence of Metarhizium anisopliae and Beauveria bassiana on Megalurothrips sjostediti, Biocontrol Sci. Technol. 9, 177-185.

Fargues J., Goettel M.S., Smits N., Ouedraogo A., Vidal C., Rougier M. (1997) Effects of temperature on vegetative growth of Beauveria bassiana isolates from different origins, Mycologia 89, 383-392.

Flores J.M., Ruiz J.A., Ruz J.M., Puerta F., Busto M. Padilla F., Campano F. (1996) Effect of temperature and humidity of sealed brood on chalkbrood development under controlled conditions, Apidologie 27, 185-192.

Goerzen D.W., Dumouchel L., Bissett J.D. (1992) Occurrence of chalkbrood caused by Ascosphaera aggregata Skou in a native leafcutting bee, $M e g$ achile pugnata Say (Hymenoptera: Megachilidae), in Saskatchewan, Can. Entomol. 124, 557558.

Goettel M.S., Duke G.M., Rank G.H. (1995) Comparisons of chalkbrood susceptibility between a French-derived univoltine strain and a Canadian strain of the alfalfa leafcutter bee, Megachile rotundata, J. Apic. Res. 34, 128.

Hall I.M. Bell J.V. (1961) Further studies on the effect of temperature on the growth of some entomophthoraceous fungi, J. Insect Pathol. 3, 289-296.

James R.R., Croft B.A., Shaffer B.T., Lighthart B. (1998) Impact of temperature and humidity on host-pathogen interactions between Beauveria bassiana and a coccinellid, Environ. Entomol. 27, 1506-1513.

Kish L.P., Waters N.D., Homan H.W. (1979) Chalkbrood. Current Information Series No. 477, Univ. Idaho Coop. Ext. Service, Agric. Exp. Stn., Moscow, Idaho.

McManus L., Youssef N.N. (1984) Life cycle of the chalk brood fungus, Ascosphaera aggregata, in the alfalfa leafcutting bee, Megachile rotundata, and its associated symptomology, Mycologia 76, 830-842.

Ouedraogo A., Fargues J., Goettel M.S., Lomer C.J. (1997) Effect of temperature on vegetative growth among isolates of Metarhizium anisopliae and $M$. flavoviride, Mycopathologia 137, 37-43.
Rust R., Torchio P.F. (1992) Effects of temperature and host developmental stage on Ascosphaera torchioi Youssef and McManus prevalence in Osmia lignaria propinqua Cresson (Hymenoptera: Megachilidae), Apidologie 23, 1-9.

SAS (1999) SAS/STAT User's Guide, Version 8. SAS Institute, Inc., Cary, NC.

Stephen W.P., Vandenberg J.D., Fichter B.L. ( 1981) Etiology and epizootiology of chalkbrood in the leafcutting bee, Megachile rotundata (Fabricius) with notes on Ascosphaera species, Oregon State University, Agric. Exp. Stn. Bull., 656.

Torchio P.F. (1992) Effects of spore dosage and temperature on pathogenic expressions of chalkbrood syndrome caused by Ascosphaera torchioi within larvae of Osmia lignaria propinqua (Hymenoptera: Megachilidae), Environ. Entomol. 21, 10861091.

Vandenberg J.D., Stephen W.P. (1982) Etiology and symptomology of chalkbrood in the alfalfa leafcutting bee, Megachile rotundata, J. Invertebr. Pathol. 39, 133-137

Vandenberg J.D. (1992) Chalkbrood susceptibility among larvae of the alfalfa leafcutting bee, $\mathrm{Meg}$ achile rotundata, from different source populations, J. Invertebr. Pathol. 60, 213-214.

Vandenberg J.D. (1994) Chalkbrood susceptibility among larvae of the alfalfa leafcutting bee (Hymenoptera: Megachilidae) reared on different diets, J. Econ. Entomol. 87, 350-355.

Vandenberg J.D., Goettel M.S. (1995) Chalkbrood susceptibility among alfalfa leafcutting bee (Hymenoptera: Megachilidae) larvae reared at different temperatures, J. Econ. Entomol. 88, 810814.

Vandenberg J.D., Stephen W.P. (1983) Pathogenesis of chalkbrood in the alfalfa leafcutting bee, $\mathrm{Meg}$ achile rotundata, Apidologie 1, 333-341.

Vidal C., Fargues J., Lacey L. (1997) Intraspecific variability of Paecilomyces fumosoroseus: effect of temperature on vegetative growth, J. Invertebr. Pathol. 70, 18-26.

Welling M., Nachtigall G., Zimmerman G. (1994) Metarhizium spp. isolates from Madagascar: morphology and effect of high temperature on growth and infectivity to the migratory locust, Locusta migratora, Entomophaga 39, 351-361.

Whitfield G.H., Richards K.W., Kveder T.M. (1987) Number of instars of larvae of the alfalfa leafcutter bee, Megachile rotundata (F.) (Hymenoptera: Megachilidae), Can. Entomol. 119, 859-865.

Youssef N.N., McManus W.R. (1991) In vitro culture of Ascosphaera aggregata (Ascosphaeraceae), a pathogen of the alfalfa leafcutting bee Megachile rotundata (Apidae), J. Invertebr. Pathol. 58, 335347. 